\title{
Preparation Method and in Vitro Evaluation Method of Rosuvastatin Porous Tablets
}

\author{
Asim Mohammed \\ Pharmacy Graduate, Faculty of Pharmaceutical Science, Mewar University, Gangrar, Chittorgarh, Rajasthan, India - 312901
}

\begin{abstract}
Rosuvastatin is an antilipemic agent that competitively inhibits hydroxymethylglutaryl-coenzyme A (HMG-CoA) reductase. HMG-CoA reducuase catalyzes the conversion of HMG-CoA to mevalonic acid, the rate-limiting step in cholesterol biosynthesis. Rosuvastatin belongs to a class of medications called statins and is used to reduce plasma cholesterol levels and prevent cardiovascular disease.This dissertation work was done with an aim to design an immediate release oral dosage of Rosuvastatin andevaluation of the tablets for various parameters including in vitro drug release studies. Rosuvastatin tablets were formulated by using microcrystalline cellulose and lactose monohydrate as fillers, camphor and menthol as subliming agents, crospovidone and CCS as super disintegrant and magnesium stearate as lubricant. The powdered blend were compressed into tablets and were analyzed for the parameters such as average weight, disintegration time, friability, thickness, weight variation, hardness, moisture content and drug content. The formulation F6 containing 10\% of camphor showed disintegration timeof less than 30seconds afterdrying.
\end{abstract}

Keywords: stability studies, Weight variation, subliming agents, Camphor

\section{Introduction}

Tablets may be defined as the solid pharmaceutical dosage forms containing drug substances with or without suitable diluents and prepared either by compression or moulding methods. They have been in wide spread use since the latter part of the $19^{\text {th }}$ century and their popularity continues. The termcompressed tablet is believed to have been first used by "JOHN WYETH".Tablets remain popular as a dosage form because of the advantages afforded both to the manufacturer and the patient.

\section{Properties of tablets}

The attributes of an acceptable tablet are as follows:

- The tablet must be sufficiently strong and resistant to shock, abrasion, should withstand handling during manufacturing, packing, shipping, and use. Hardness and friability tests measure this property.

- Tablet must be uniform in weight and in drug content of the individual tablet. This is measured by the weight variation and content uniformity tests.

- The drug content of the tabletmust be bioavailable. This property is measured by the dissolution test. Accurate bioavailability can be obtained from the drug levels in the blood after its administration.

- Tablets must be elegant in appearance, characteristic shape, color and other markings necessary to identify the product.

- Tablets must retain all these functional attributes which include drug stability and efficacy.

\section{Materials and Methods}

Rosuvastatin, Avicel pH 102 (Microcrystalline cellulose), Lactose Monohydrate, Magnesium stearate, Camphor, Menthol, Croscarmellose sodium, Cross povidone. Formula for the Rosuvastatin porous tablet tabulated in the Table No.1.
1) Precompression characteristics

Before going to the formulation the powder flow properties like Bulk density, Tapped density, True density, Angle ofRepose, Compressibility index andHausner's ratio were performed and theresults were tabulated in the Table No.3. i.e. Bulk density

Bulk density of a compound varies substantially with the method of crystallization, milling or formulation. Bulk density is determined by pouring pre sieved blend into a graduated cylinder via a large funnel and measure the volume and weight.

\section{Bulk density $=$ Weight of blend Bulk volume of blend}

Bulk density was expressed in $\mathrm{g} / \mathrm{cc}$.

\section{2) Tapped density}

Tapped density is determined by placing a graduated cylinder containing a known mass of blend and mechanical tapper apparatus, which is operated for a fixed number of taps until the powder bed volume has reached a minimum volume. using the weight of the drug in the cylinder and this minimum volume, thetaped density may be computed.

$\mathbf{D t}=\mathbf{M} / \mathbf{V} \mathbf{t D t}=$ Tapped densityM $=$ weight of blend

$\mathrm{Vt}=$ Tapped volume of blend

\section{3) Carr's Index (CI)}

Carr's index is measured using the values of bulk density and tapped density. The following equation is used to find the Carr's index.

$$
C I=(T D B D) \times 100
$$

TD

Where $\mathrm{TD}=$ Tapped densityBD $=$ Bulk density

\section{4) Hausner's Ratio}

It indicates the flow properties of the powder and ratio of Tapped density to the Bulk density of the powder or blend.

Hausner's Ratio = Tapped density/Bulk density v.Angle 
of repose

The manner in which stresses are transmitted through a bead and the beads response to applied stress are reflected in the various angles of friction and response. The method used to find the angle of repose is to pour the powder iona conical heat on a level, flat surface and measure the included angle with the horizontal.

\section{$\operatorname{Tan} \theta=\mathbf{h} / \mathbf{r}$}

Where, $\mathrm{h}=$ height of the heap

$\mathrm{r}=$ Radius of the heap

\section{Post Compression Studies}

\section{1) Tablet Thickness Test}

Randomly 10 tablets were taken from each formulation trial batch and their thickness was measured using a Venire caliperse.

\section{2) Weight Variation Test}

The weight variation test is carried out in order toensure uniformity in the weight of tablets in a batch. The total weight of 20 tablets from each formulation was determined and theaverage was calculated. The individual weights of the tablets were also determined accurately and the weight

variation was calculated.

\section{3) Measurement of Tablet Hardness}

The hardness of tablet is an indication ofits strength. The force is measured in $\mathrm{kg}$ and the hardness of about 3-5 $\mathrm{kg} / \mathrm{cm} 2$ is considered to be satisfactory for uncoated tablets. Hardness of 10 tablets from each formulation was determined by Monsantohardness tester.

\section{4) Friability Test}

It is measured of mechanical strength of tablets. Roche Friabilator is used to determine the friability by following procedure. Twenty tablets were weighedand placed in Roche Friabilator where the tablets were exposed to rolling and repeated shocks resulting from free falls within the apparatus. After 100 revolutions, tablets are removed, dedusted and weighed again. The friability was determined as thepercentage loss in weight of the tablets.

$\%$ Friability $=($ loss in weight $/$ Initial weight $) X 100$

Post compression results were showed in the Table No.4.

\section{Methodology}

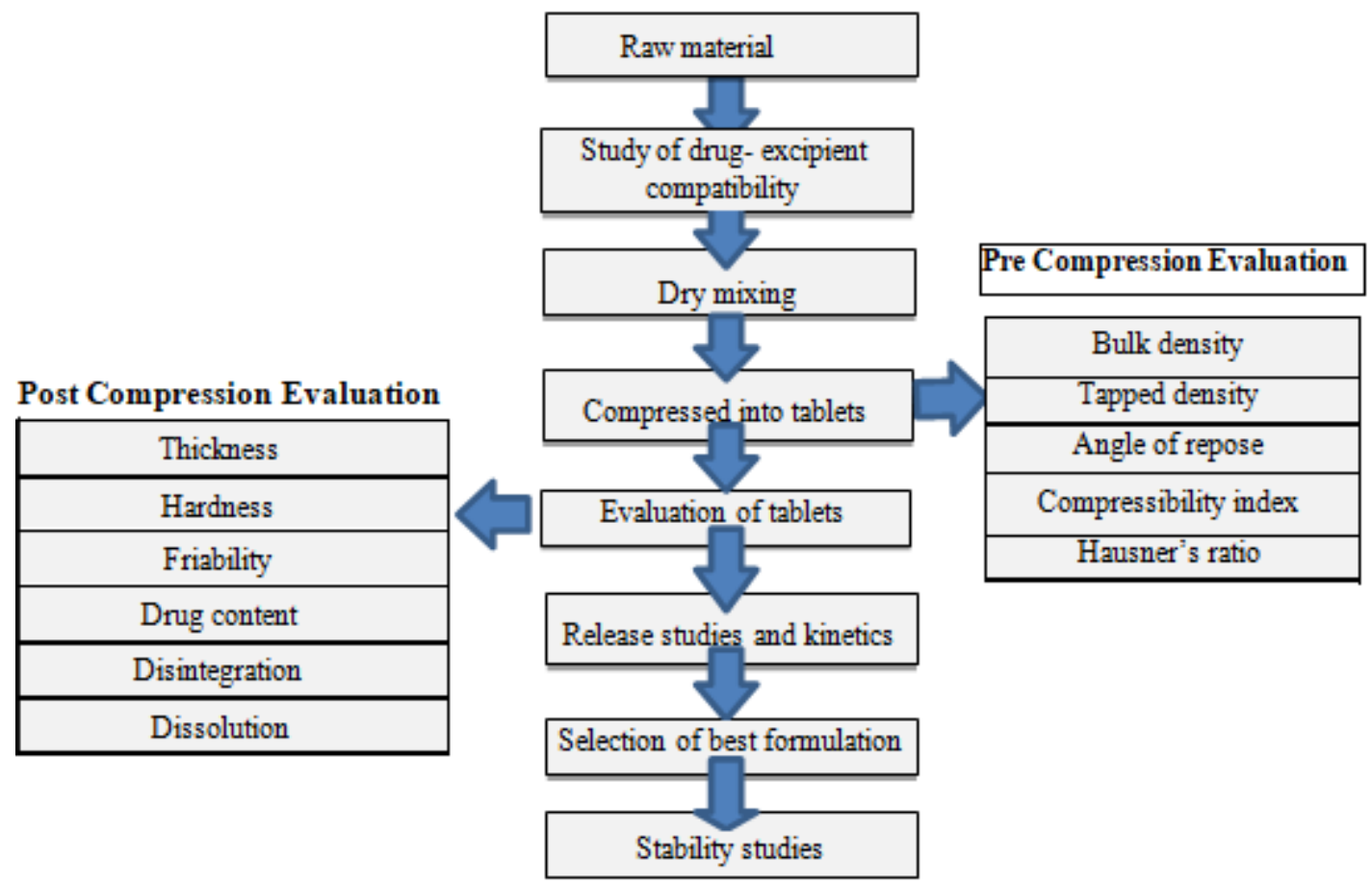

Figure 1: Flow chart representing the process involved in the preparation of tablets

Dissolution parameters Medium: $0.1 \mathrm{~N}$ HCL, $900 \mathrm{ml}$. Apparatus: USP Type 2 (paddle). Rotation speed: 50 RPM Temperature: $37 \pm 5^{0} \mathrm{C}$.

Time: 10, 15, 20, 30, 45 and 60 min.

\section{Results and Discussions}

Immediate release tablets of Rosuvastatin were formulated by direct compression method using Camphor and Menthol as subliming agents, Microcrystalline cellulose, Lactose monohydrate as diluents, CCS as super disintegrant, Magnesium stearate as lubricant.
Compatibility studies were performed using IR spectrophotometer. The IR spectrum of pure drug and physical mixture of drug and excipients were studied as shown in Figures 9.3, 9.4, 9.5 and 9.6. The peaks obtained in the spectra's of each formulation correlates with the peaks of drug spectrum. This indicates that the drug is compatible with the formulation components.

The blends were analyzed for parameters such as Sieve analysis, Bulk density, Tapped density, Compressibility index and Hausner's ratio and the results were found to be within limits. 
Bulk density and tapped density values were found to be within limits. Compressibility index has been proposed as an indirect measure of bulk density, size and shape, surface area and cohesiveness of material. The powdered blend has required flow property.

After compression, all the tablets were dried at $60^{\circ} \mathrm{C}$ for $12 \mathrm{hrs}$ and wereevaluated for various parameters like weight variation, hardness, thickness, friability, disintegration and in-vitro drug release. All formulations were found to have good hardness so they were taken for further studies. The measured hardness of tablets of each batch are in the range of 6 to $6.5 \mathrm{kp}$.

Tablets mean thickness were almost uniform in all formulations and were found to be in the range of $2.40 \mathrm{~mm}$ to $2.6 \mathrm{~mm}$.

Friability values are found to be less than $1 \%$ in all the cases and considered to be satisfactory.

The total weight of each formulation was maintained constant and the weight variation of the tablets was within limits of $5 \%$.

All the tablets passed the pharmacopoeial specifications for disintegration of Rosuvastatin porous tablets within 3 minutes. The first trial (F1) was performed by direct compression using 5\% of camphor as subliming agent and it was observed that the disintegration time of the product was on higher side. The reason behind this is due to closure of pores of the granules at the time of compression. In order to overcome this problem next trials (F2) using menthol remaining concentrations were planned using higher concentrations of super disintegrants and subliming agent.

The optimized formulation F6 containing 10\% of menthol showed in-vitro drug release of almost $98.06 \%$ of Rosuvastatin in $45 \mathrm{mins}$ and the disintegration time was found to be $42 \mathrm{sec}$. The tablets loaded for stability at $40 \mathrm{oC}$ and $75 \% \mathrm{RH}$ for 1 month and 3 months respectively did not show much effect on the dissolution and drug content and are within the limits as per ICH guidelines therefore ensuring that the formulation F6 is a stable formulation.

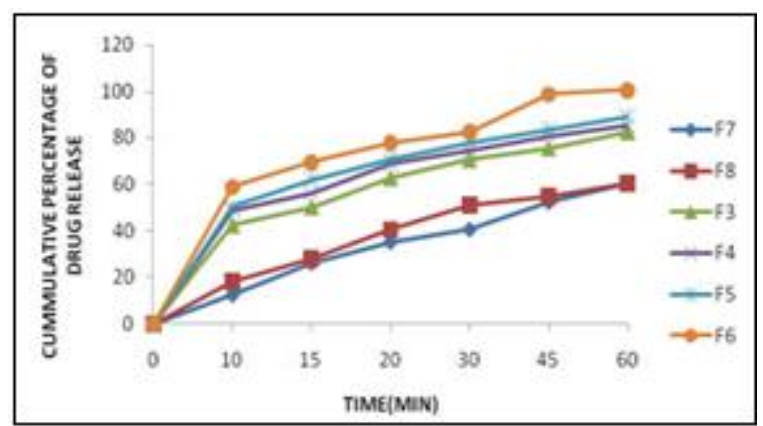

Figure 1: In-Vitro Release Profile of Rosuvastatin from formulations F1-F6

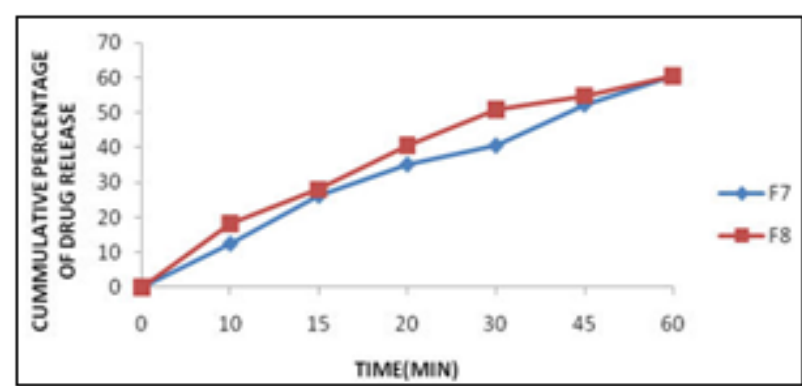

Figure 2: In-Vitro Release Profile of Rosuvastatin from formulations F7\&F8

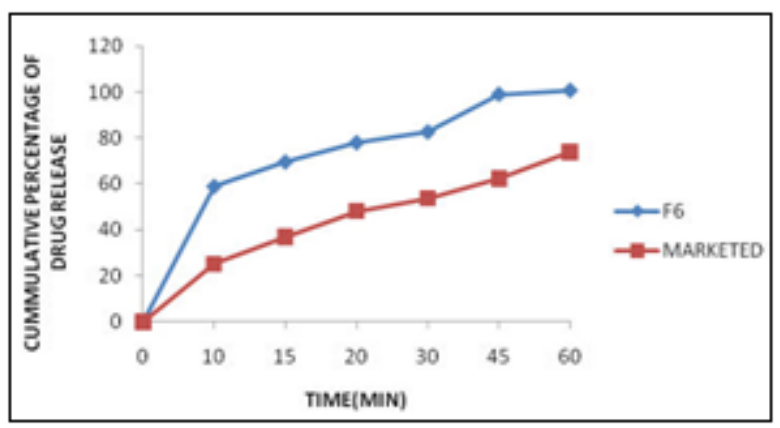

Figure 3: Comparison of In-Vitro Release Profile of formulation F6 withMarketed formulation

\section{Conclusion}

This dissertation work was done with an aim to design an immediate release oral dosage of Rosuvastatin and evaluation of the tablets for various parameters including in vitro drug release studies.

Rosuvastatin tablets were formulated by using microcrystalline cellulose andlactose monohydrate as fillers, camphor and menthol as subliming agents, crospovidone and CCS as super disintegrant and magnesium stearate as lubricant.

The powdered blend were compressed into tablets and were analyzed for the parameters such as average weight, disintegration time, friability, thickness, weight variation, hardness, moisture content and drug content.

The formulation F6 is formulated byusing subliming agents and super disintegrants where it can ensure burst release of both the drugs so that there release cannot be interlinked.

The formulation F6 containing 10\% of camphor showed disintegration time of less than 30seconds after drying. Camphor as subliming agent was found tobe most effective of all other subliming agents as it had showed drastic effect on the drug release. All other parameters viz: Hardness, Thickness, Weight variation and drug content were also found to be within limits.

The dissolution profiles and drug content of the tablets were found to be satisfactory even after subjecting the tablets to stability studies at $40^{\circ} \mathrm{C}$ and $75 \% \mathrm{RH}$ for 1 month and 3 months respectively.

The formulation F6 and process can beeasily scaled up and can be easily employed in large scale production because the 
process is simple, cost effective and precise and also yields for manufacturing thetablets. reproducible good result that involves complex process

Table 1: Composition of Formulations

\begin{tabular}{|c|c|c|c|c|c|c|c|c|}
\hline Ingredients & F1 & F2 & F3 & F4 & F5 & F6 & F7 & F8 \\
\hline Rosuvastatin & $10 \mathrm{mg}$ & $10 \mathrm{mg}$ & $10 \mathrm{mg}$ & $10 \mathrm{mg}$ & $10 \mathrm{mg}$ & $10 \mathrm{mg}$ & $10 \mathrm{mg}$ & $10 \mathrm{mg}$ \\
\hline Camphor & 10 & -- & 20 & -- & 20 & -- & -- & -- \\
\hline MCC & 127 & 127 & 113 & 113 & 105 & 105 & 105 & 105 \\
\hline LM & 42 & 42 & 42 & 42 & 42 & 42 & 42 & 42 \\
\hline Menthol & -- & 10 & -- & 20 & -- & 20 & 20 & 20 \\
\hline CCS & $8 \mathrm{mg}$ & $8 \mathrm{mg}$ & $12 \mathrm{mg}$ & $12 \mathrm{mg}$ & $20 \mathrm{mg}$ & $20 \mathrm{mg}$ & -- & -- \\
\hline CP & -- & -- & -- & -- & -- & -- & $12 \mathrm{mg}$ & $20 \mathrm{mg}$ \\
\hline Mg.stearate & $3 \mathrm{mg}$ & $3 \mathrm{mg}$ & $3 \mathrm{mg}$ & $3 \mathrm{mg}$ & $3 \mathrm{mg}$ & $3 \mathrm{mg}$ & $3 \mathrm{mg}$ & $3 \mathrm{mg}$ \\
\hline Total weight & $200 \mathrm{mg}$ & $200 \mathrm{mg}$ & $200 \mathrm{mg}$ & $200 \mathrm{mg}$ & $200 \mathrm{mg}$ & $200 \mathrm{mg}$ & $200 \mathrm{mg}$ & $200 \mathrm{mg}$ \\
\hline
\end{tabular}

Table 2: Table showing the bulk density of the API's

\begin{tabular}{|c|c|c|c|c|c|c|}
\hline Material & $\begin{array}{c}\text { Bulk density } \\
(\mathrm{gm} / \mathrm{mL})\end{array}$ & $\begin{array}{c}\text { Tapped density } \\
(\mathrm{gm} / \mathrm{mL})\end{array}$ & $\begin{array}{c}\text { Compressibility } \\
\text { index }(\%)\end{array}$ & $\begin{array}{c}\text { Hausner's } \\
\text { ratio }\end{array}$ & $\begin{array}{c}\text { Angle of } \\
\text { repose }\end{array}$ & $\begin{array}{c}\text { Flow } \\
\text { property }\end{array}$ \\
\hline Rosuvastatin & $0.472 \mathrm{gm} / \mathrm{mL}$ & $0.510 \mathrm{gm} / \mathrm{mL}$ & $26.62 \%$ & 1.36 & $45^{\circ} \mathrm{c}$ & Passable \\
\hline
\end{tabular}

Table 3: Pre-compression parameters for formulation batches

\begin{tabular}{|c|c|c|c|c|c|c|}
\hline $\begin{array}{c}\text { Formulation } \\
\text { code }\end{array}$ & $\begin{array}{c}\text { Bulk density } \\
(\mathrm{gm} / \mathrm{mL})\end{array}$ & $\begin{array}{c}\text { Tapped density } \\
(\mathrm{gm} / \mathrm{mL})\end{array}$ & $\begin{array}{c}\text { Compressibility } \\
\text { index }(\%)\end{array}$ & $\begin{array}{c}\text { Hausner's } \\
\text { ratio }\end{array}$ & $\begin{array}{c}\text { Angle of } \\
\text { repose }\end{array}$ & Flow property \\
\hline F1 & $0.721 \pm 0.045$ & $0.87 \pm 0.01$ & $17.126 \pm 0.6$ & $1.206 \pm 0.06$ & $36.62 \square 0.21$ & Fair \\
\hline F2 & $0.710 \pm 0.043$ & $0.873 \pm 0.04$ & $19.714 \pm 0.7$ & $1.251 \pm 0.04$ & $37.46 \square 0.11$ & Fair \\
\hline F3 & $0.41 \pm 0.045$ & $0.483 \pm 0.5$ & $15.113 \pm 0.8$ & $1.178 \pm 0.08$ & $38.32 \square 0.31$ & Fair \\
\hline F4 & $0.45 \pm 0.045$ & $0.52 \pm 0.09$ & $15.60 \pm 0.2$ & $1.15 \pm 0.02$ & $28.06 \square 0.31$ & Very good \\
\hline F5 & $0.45 \pm 0.045$ & $0.50 \pm 0.07$ & $12.23 \pm 0.6$ & $1.11 \pm 0.04$ & $27.58 \square 0.15$ & Very good \\
\hline F6 & $0.44 \pm 0.044$ & $0.50 \pm 0.09$ & $12.58 \pm 0.8$ & $1.13 \pm 0.08$ & $28.44 \square 0.11$ & Very good \\
\hline F7 & $0.41 \pm 0.048$ & $0.483 \pm 0.49$ & $15.113 \pm 0.9$ & $1.178 \pm 0.07$ & $38.32 \square 0.33$ & Fair \\
\hline F8 & $0.710 \pm 0.032$ & $0.873 \pm 0.036$ & $19.714 \pm 0.6$ & $1.251 \pm 0.05$ & $37.46 \square 0.15$ & Fair \\
\hline
\end{tabular}

Table 4: Evaluation parameters of formulations of porous tablets before drying

\begin{tabular}{|c|c|c|c|c|c|c|}
\hline $\begin{array}{c}\text { Formulation } \\
\text { code }\end{array}$ & $\begin{array}{c}\text { Thickness } \\
(\mathrm{mm})\end{array}$ & $\begin{array}{c}\text { Hardness } \\
(\mathrm{KP})\end{array}$ & $\begin{array}{c}\text { Friability } \\
(\%)\end{array}$ & $\begin{array}{c}\text { Average weight } \\
\text { variation }(\mathrm{R}(\mathrm{mg})\end{array}$ & $\begin{array}{c}\text { Drug content } \\
\text { osuvastatin }(\%)\end{array}$ & $\begin{array}{c}\text { Disintegration } \\
\text { Time } \pm \text { S.D. (min) }\end{array}$ \\
\hline F1 & 3.29 & 5.0 & 0.54 & 202.1 & $99.13 \pm 0.53$ & 4.2 \\
\hline F2 & 3.05 & 3.5 & 0.45 & 205.6 & $96.27 \pm 0.64$ & 3.3 \\
\hline F3 & 3.38 & 3.5 & 0.35 & 201.8 & $97.63 \pm 0.55$ & 4.5 \\
\hline F4 & 3.50 & 3.5 & 0.41 & 201.9 & $98.36 \pm 0.58$ & 3.4 \\
\hline F5 & 3.43 & 5.0 & 0.42 & 205.4 & $98.33 \pm 0.62$ & 4.3 \\
\hline F6 & 3.27 & 3.5 & 0.31 & 203.6 & $98.64 \pm 0.84$ & 2.9 \\
\hline F7 & 3.38 & 4.1 & 0.26 & 2016 & 99.2 & 7 mins 10 secs \\
\hline F8 & 3.36 & 4.1 & 0.23 & 202.0 & 98.6 & 7 mins 5 secs \\
\hline
\end{tabular}

Table 5: Evaluation parameters for formulations of porous tablets after drying

\begin{tabular}{|c|c|c|c|c|c|}
\hline $\begin{array}{c}\text { Formulation } \\
\text { code }\end{array}$ & $\begin{array}{c}\text { Thickness } \pm \text { S.D. } \\
(\mathrm{mm})\end{array}$ & $\begin{array}{c}\text { Hardness } \\
\pm \text { S.D. }(\mathrm{Kp})\end{array}$ & $\begin{array}{c}\text { Average weight } \\
\text { variation }(\mathrm{mg})\end{array}$ & $\begin{array}{c}\text { Drug content } \\
(\text { Rosuvastatin) }(\%)\end{array}$ & $\begin{array}{c}\text { Disintegration } \\
\text { Time } \pm \text { S.D. }\end{array}$ \\
\hline F1 & 3.29 & 3.7 & 201.3 & 99.26 & $1 \mathrm{~min} 10 \mathrm{sec}$ \\
\hline F2 & 3.05 & 3.8 & 203.2 & 96.38 & $43 \mathrm{sec}$ \\
\hline F3 & 3.38 & 4.1 & 200.9 & 97.03 & $1 \mathrm{~min}$ \\
\hline F4 & 3.50 & 4.1 & 200.00 & 98.26 & $36 \mathrm{sec}$ \\
\hline F5 & 3.43 & 4.2 & 203.4 & 98.29 & $57 \mathrm{sec}$ \\
\hline F6 & 3.27 & 4.8 & 201.8 & 98.60 & $20 \mathrm{sec}$ \\
\hline F7 & 3.38 & 4.3 & 200.9 & 99.36 & 5 mins \\
\hline F8 & 3.36 & 4.3 & 200.3 & 99.56 & 5 mins 34 secs \\
\hline
\end{tabular}

Table 6: In-Vitro Release Profile of Rosuvastatin from formulations F1-F8

\begin{tabular}{|c|c|c|c|c|c|c|c|c|c|c|}
\hline \multirow{2}{*}{ S. No. } & \multirow{2}{*}{ Time (min) } & \multicolumn{8}{|c|}{ Cumulative \% drug release } \\
\cline { 3 - 11 } & & F1 & F2 & F3 & F4 & F5 & F6 & F7 & F8 & Marketed \\
\hline 1 & 10 mins & 32.56 & 38.26 & 42.52 & 48.96 & 50.38 & $\mathbf{5 8 . 9 2}$ & 12.56 & 18.26 & 25.23 \\
\hline 2 & 15 mins & 46.28 & 48.03 & 50.36 & 56.48 & 61.94 & $\mathbf{6 9 . 5 2}$ & 26.28 & 28.03 & 36.88 \\
\hline 3 & 20 mins & 55.23 & 60.58 & 62.85 & 68.92 & 70.56 & $\mathbf{7 7 . 8 9}$ & 35.23 & 40.58 & 48.12 \\
\hline 4 & $30 \mathrm{mns}$ & 60.65 & 65.92 & 70.59 & 74.56 & 77.89 & $\mathbf{8 2 . 5 6}$ & 40.65 & 50.92 & 53.64 \\
\hline 5 & 45 mins & 72.36 & 74.82 & 75.62 & 80.82 & 83.56 & $\mathbf{9 8 . 9 4}$ & 52.36 & 54.82 & 62.18 \\
\hline 6 & 60 mins & 80.56 & 80.49 & 82.51 & 85.45 & 88.95 & $\mathbf{1 0 0 . 5 9}$ & 60.56 & 60.49 & 73.82 \\
\hline
\end{tabular}




\section{References}

[1] Bokshi B, Malakar A. Formulation and evaluation of allylestrenol immediate release tablets. Int. J. Pharm. Sci. Res. 2012; 3:1679-83.

[2] Yeole CN, Darekar SS, Gupta A, Shrinivasan G. Formulation and evaluation of immediate releasetablet of paroxetine HCl. J. Pharm. Res. 2010; 3:1736-8.bet

[3] Hu RF, Zhu JB, Peng DY, Tang JH, Zhou A. Optimization of formulation of Fufang Danshen immediate release tablet by colligation score. Zhongguo Zhong Yao Za Zhi 2006; 31:380-2.

[4] Shiyani B, Gattani S, Surana S. Formulation and Evaluation of Bilayer Tablets of Metoclopramide hydrochloride and Ibuprofen. AAPS Pharm. Sci. Tech. 2008 sep; 9(3): 818-27.

[5] Mandal U, Pal TK. Formulation and In Vitro Studies of a Fixed Dose Combination of a Bilayer Matrix Tablet Containing Metformin $\mathrm{HCl}$ as Sustained Release and Glipizide as Immediate Release. Drug Dev. and Industrial Pharm. 2008; 34(3): 305-13.

[6] Atram SC, Udavant YK, Salunke RJ, Neb GB, Shahi $\mathrm{SR}$ et al. Formulation of bilayer tablet containing metoprolol succinate and amlodipine besylate as a model drug for antihypertensive therapy. J. Pharm. Res. 2009; 2(8): 1335- 47.

[7] Kulkarni A, Bhatia M. Developmentand Evaluation of regioselective bilayer floating tablets of Atenolol and Lovastatin for biphasic release profile. Iranian $\mathrm{J}$. Pharm. Res. 2009; 8(1): 15-25.

[8] Kannan K, Manikandan M, Selvamuthukumar S, Manavalan R. Formulation development and evaluation of emtricitabine and tenofovir disoproxil fumaratetablets. Int. J. Dev. and Res. 2012;04(01):24756.

[9] Kaushic. Review on mouth dissolving tablets, Indian drugs;2004; 41(4): 187-93.

[10] Lalla J K and Mamania H M. Fast Dissolving Rofecoxib Tablets. Ind. Jof pharm sci. 2004; 350-2.

[11] Rao MRP, Bachhav D, Gogad V. Formulation and evaluation of Aceclofenac immediate release tablets. The Ind Pharmacist2007;6(61):73-78.

[12] Valentina R, Alberto R, Giorgio R, Monica C. Increased absorption rate of Diclofenac from fast acting formulation containing its potassium salt. Arzneimittel-Forschung 2001;51(11):885-90.

[13] Tavakolin, A Mostafavi, MDehghan, M Dehghani, Z Rafeipour. Drug release evaluation of Ibuprofen sugar coated and film coated tablets marketed in iran. Armaghan Danesh2005;10(3(39)):25-34.

[14] Patel HP, Karwa P, Bukka R, Patel NJ. Formulation and evaluation of immediate release tablets of Zolpidem Tartrate by direct compression. Int J Pharm SciReview Res 2011;7(2):80-85.

[15] Patil J, Kadam C, V Vishwajit, V Gopal. Formulation, design and evaluation of orally disintegrating tablets of Loratadine using direct compression process. Int $\mathrm{J}$ Pharm Bio Sci 2011;2(2):389-99.

[16] Kawano, Ito Y, Sastsu A, Machida M, Onishi Y. Preperation and evaluation of taste masked orally disintegrating tablets with granules made by wet granulation method. J Pharm Soc Japan 2010;130(12):1737-42.
[17] Preetha B, Pandit JK, Rao VU, Bindu K, Rajesh YU, Balasubramanian J. Comparativeevaluation of mode of incorporation of superdisintegrants on dissolution of model drugs from wetgranulation tablets. Acta Pharma Sci 2008; 50:229-36.

[18] Saville DJ. Influence of storage on in-vitro release of Ibuprofen from sugar coated tablets. Int J Pharma 2001;224:39-49. 